\title{
BREASTFEEDING PRETERM INFANTS AT HOME
}

\author{
Flávia Corrêa Porto de Abreu², Bruna de Souza Lima Marski, Natália Custódio ${ }^{4}$, Soraya Cirilo Carvalho ${ }^{5}$, \\ Monika Wernet ${ }^{6}$
}

${ }^{1}$ Research supported by the São Paulo Research Foundation, process 2012/00499-2.

${ }^{2}$ M.Sc in Nursing. Universidade Federal de São Carlos (UFSCar). São Carlos, São Paulo, Brazil. E-mail: flaviacpa90@gmail.com

${ }^{3}$ Undergraduate student at the Nursing Program of UFSCar. São Carlos, São Paulo, Brazil. E-mail: bmarski@gmail.com

${ }^{4}$ M.Sc. in Nursing. São Carlos, São Paulo, Brazil. E-mail: custodionati@gmail.com

${ }^{5}$ M.Sc in Nursing, UFSCar. São Carlos, São Paulo, Brazil. E-mail: sorayacirilo@hotmail.com

${ }^{6}$ Ph.D. in Nursing. Adjunct Professor of the Department of Nursing, UFSCar. São Carlos, São Paulo, Brazil. E-mail: monika. wernet@gmail.com

\begin{abstract}
The aim of this study was to analyze the experience of mothers regarding the breastfeeding of preterm newborns during the first month after discharge from the neonatal intensive care unit. Its theoretical framework was the symbolic interactionism and its methodological framework was qualitative content analysis. Nine mothers were interviewed. Results were described using three categories: 'professional relationships and breastfeeding', 'unique traits of breastfeeding preterm infants' and 'responsibilities for nourishing infants'. Results show that mixed feeding is how mothers feed their preterm infants at home, given the fact that they are insecure and uncertain that their milk is enough. Health workers contribute to that understanding, and health practices must be transformed.
\end{abstract}

DESCRIPTORS: Breast feeding infantile. Premature infant. Patient discharge.

\section{ALEITAMENTO MATERNO DO PREMATURO EM DOMICÍLIO}

RESUMO: O presente estudo teve por objetivo analisar a experiência da mãe acerca do aleitamento materno do recém-nascido prematuro ao longo do primeiro mês após a alta da unidade de cuidados intensivos neonatal. Adotou como referencial teórico o Interacionismo Simbólico e como referencial metodológico a análise de conteúdo qualitativa. Nove mães foram entrevistadas. Os resultados foram descritos a partir de três categorias: 'relações profissionais e aleitamento materno', 'particularidades do aleitamento materno em prematuro' e 'responsabilidade pela alimentação do(s) filho(s)'. Revela ser o aleitamento misto a forma como as mães alimentam o filho prematuro em domicílio, dada a insegurança e incerteza da suficiência do leite materno. Os profissionais de saúde contribuem para tal entendimento com necessidade de transformar as práticas em saúde.

DESCRITORES: Aleitamento materno. Prematuro. Alta do paciente.

\section{LACTANCIA MATERNA DEL BEBÉ PREMATURO EN EL HOGAR}

RESUMEN: El presente estudio tuvo como objetivo analizar la experiencia de la madre que amamanta el bebé prematuro durante el primer mes después del alta de la unidad de cuidados intensivos neonatales. Fue adaptado como el marco teórico el Interaccionismo Simbólico y como el marco metodológico la análisis de contenido cualitativo. La entrevista tuvo lugar con nueve madres. Los resultados se muestran a partir de tres categorias: 'Las relaciones profesionales y la lactancia materna', 'particularidades de la lactancia materna en prematuros' y 'La responsabilidad por alimentación de lo hijos'. Demostrar que la lactancia materna mixto es la forma como las madres alimentan al niño prematuro en el hogar, dada la inseguridad y la duda de la suficiencia de la leche materna. Profesionales de la salud contribuyen a esa comprensión con la necesidad de transformar las prácticas de salud.

DESCRIPTORES: Lactancia materna. Prematuro. Alta del paciente. 


\section{INTRODUCTION}

The World Health Organization (WHO), ${ }^{1}$ the United Nations Children's Fund (UNICEF) ${ }^{2}$ and the Brazilian Ministry of Health (MS) recommend exclusive breastfeeding with human milk (HM) from birth up to six months of age. After that period (up to two years of age or beyond), complementary food should be administered in addition to breastfeeding. They consider this a natural strategy for building bond, affection, protection and nutrition for the infants, while also contributing for decreasing infant mortality and for a sustainable development. ${ }^{3}$

Breastfeeding (BF) of preterm infants has unique traits, with early weaning being common, ${ }^{4-5}$ especially because of the delay in directly suckling the mother's breast, infant hospitalization, maternal and family stress, and gaps in BF encouragement and support in this context. ${ }^{5}$

However, there is a consensus regarding $\mathrm{HM}$ as the ideal feeding for preterm newborns (PTNs). ${ }^{4-5}$ Therefore, preserving maternal lactation and exclusive breastfeeding are strategic actions. ${ }^{5}$ Supporting and encouraging PTN breastfeeding ensures higher quality of life, ${ }^{4,6}$ growth, and development, ${ }^{4-6}$ because it fosters the mother-child bond, ${ }^{4}$ decreases weight loss, ${ }^{4-5}$ stimulates and matures the immune and digestive systems of infants, ${ }^{4}$ among other benefits.

Therefore, breastfeeding preterm infants has unique traits that, if not properly administered, may hinder it and/or cause early weaning. ${ }^{4-5}$

Facing the problem of breastfeeding PTNs, the research questions were: "How do mothers experience the PTNs' feeding at home?" and "Where does BF fit in this context?". The aim of the study was to analyze the mothers' experiences regarding the breastfeeding of PTNs during the first month after discharge from the Neonatal Intensive Care Unit (NICU).

\section{METHOD}

This study focuses on the maternal experience of feeding PTNs after hospital discharge, which entails learning beliefs, values, meanings and making decisions about their infants nourishment. Therefore, we opted for the theoretical framework of symbolic interactionism (SI), which uses meanings established in social interactions to address human behavior. ${ }^{7}$ It asserts that it is in and through social interaction that symbolic interpretations and meanings are continuously built and rebuilt. ${ }^{7}$
In accordance with the selected theoretical framework, qualitative content analysis (CA) was an appropriate methodological framework, since it focuses on understanding the products of communication and aims to describe a phenomenon conceptually. ${ }^{8-9}$

Semi-structured interviews were used to collect data, guided by the following propositions: 'Tell me about how you are feeding your infant at home', 'How did you decide to do that?' and 'What do you think of breastfeeding PTNs?".

The interviews took place at the women's homes or in a follow-up service for infants at risk in a city in the countryside of the state of São Paulo, where potential subjects were selected. All recommendations for research with human beings were observed and a Research Ethics Committee approved the research proposal, under protocol number 115/2012. All interviews were recorded with a digital audio device in order to easily obtain the narratives and to avoid the loss of important data.

Material analysis followed the inductive CA structure, ${ }^{9}$ which has the following steps: 1 ) transcription of the interview followed by reiterative readings of the manual to understand the meaning of the whole and the manifested and hidden contents, which enable the identification of units of analysis; 2) organization of material through codification and the creation of categories; and 3) reporting of the analytical process and results, ${ }^{9}$ when we opted to conduct it through temporal triggering. ${ }^{8}$

Data were collected between June and December 2013. The number of participating subjects was not previously defined. There was a concern with the researched phenomenon and the potential for subjects to contribute empirically to the object. ${ }^{10}$ Thus, results were derived from interviews with nine women who met the inclusion criteria of the study: being mothers of infants who were admitted to the NICU; infants with a gestational age between 24 and 32 weeks at birth; infants with no congenital morbidities or genetic syndromes; having started breastfeeding the infant at the NICU; being over 18 years of age.

To preserve the participants' anonymity, they were identified in the study by the letter " $\mathrm{M}$ " followed by the number that defines the order in which they were interviewed. For example, the last interviewed mother was identified as 'M9'. 


\section{RESULTS}

The interviewees were aged between 27 and 40 years. Two were mothers of twins, three already had older children and four were first-time mothers. Moreover, seven were married. All of them were experiencing prematurity for the first time. The length of the infants' hospitalization period was between 1 and 4 months and gestational age at birth was between 27 and 31 weeks. All of them were on mixed feeding, with a predominance of baby formula.

Mothers experience BF at home with feelings of insecurity and uncertainty concerning the sufficiency of HM for nourishing, clinical stability and the infants' recovery. These elements are assessed through the infants' weight gain, a parameter that is learned at the NICU, reinforced in the followups and a limiter for PTNs' breastfeeding at home. The categories 'professional relationships and $\mathrm{BF}^{\prime}$, 'unique traits of breastfeeding preterm infants' and 'responsibilities for feeding infants' compose the description of the PTNs' breastfeeding at home phenomenon.

\section{Professional relationships and breastfeeding}

During the stay at the NICU, the relational context with the workers gives mothers the understanding that their infants are fragile and at-risk, in need of attentive and thorough care. It also gives them the understanding that the workers hide information related to the infants' status, especially when it worsens. Because of that, mothers adopt a distrustful attitude, looking for information through means other than interactions with workers to understand the clinical status of their infants. As a result, they feel the need to "see to believe".

[...] the workers only tell you half of everything, right, if you are not present during shift change, you don't really know what happened to your child. [...] I used to arrive early, I used to hear everything they said about my children, and when they [the workers] came to tell me, they didn't tell me everything, they only told me what was convenient. What wasn't convenient, they didn't tell me. Other mothers asked how their children were going and they told them they were fine, but I heard them say that the children had cried all night long, that they were agitated, and they told them that the kids were fine the whole night (M1).

In addition to this scenario, there is a predominance of workers that talk to the mothers with a surly and blunt tone, which traumatizes them. Over time, relationships become almost unsus- tainable, driving some mothers to avoid them by not going to the NICU or to the follow-up service.

There was a doctor who was very blunt, she straight up tells you that the status of your child is very delicate. [...] you, you're already traumatized, you're already feeling bad because you are in the ICU, [...] you are already feeling tense for being there and the doctor simply tells you: "oh, you know it's hard, don't you? You know that he may live or die. Oh, so it's very hard, the situation is very serious", these words are hurtful, because, you know, there are other ways to talk to people. [...] when I know she will be there, I don't even show up. She also works at the [name of the follow-up service] and I don't go when she is there (M2).

Regarding BF, specifically, this relational context affects the mothers' and the families' confidence and security in relation to professional information, especially when it comes to the infants' weight loss after hospital discharge. They learned at the NICU that weight corresponds to the infants' recovery and that its loss corresponds to their worsening. The sum of these two parameters makes mothers and their families question if BM is enough for the children. Moreover, in the first consultations in the follow-up service, the issue of weight is strongly reinforced as a parameter that shows the evolution of the children and adequate maternal care, with explicit threats of readmitting the children if they do not stabilize.

My son should not lose weight, and they [workers from the follow-up service] used to say: 'he should not lose weight, because if he does, he may contract a worse disease and be hospitalized again'. That was my fear. I thought: no way is he going back to the hospital. That was my worst fear when I went back home and he lost weight in the first week. I thought: is my milk weak? (M4).

Special attention should be given to the fact that in the early period of hospitalization at the NICU, which coincides with the beginning of breast milk production and adaptation of mothers to the act of $\mathrm{BF}$, the women receive ambivalent speeches from the workers. Sometimes, they reinforce the restrictive aspects of BF in the preterm situation, while emphasizing the infants' limitations in the process of connecting to the nipple and sustaining the nourishment. At other times, they speak about the nutritional value and the digestive specificity of BM for preterm infants, while encouraging the practice. In this context, speeches related to the restrictive aspects are remembered, and they come back to the mothers when they have difficulties while breastfeeding. However, 
the decision to breastfeed usually prevails, and the women try to handle, in their minds, the impact of the restrictive aspects transmitted while interacting with the workers.

There are professionals whose speeches and attitudes show faith in the mothers' and infants' capacity to perform BF exclusively. They encourage and increase the desire and struggle of the women to exclusively breastfeed their preterm infants, even while facing possible difficulties.

I always wanted to breastfeed, but everybody used to say: 'he won't latch on, he is tiny', and I used to say: 'yes, he'll latch on'. They [nursing technicians] used to say 'Doctor, I won't even deceive the mother', I wanted to punch them in the face. Instead of saying: 'no, he'll latch on', [...] I just wanted to cry. Then, when the doctor said: "no, he'll latch on, put him in position that he'll latch on, prepare her', I was so happy, it was a relief, he suckled until milk dripped from the corner of his mouth. [...] but I tell you this: I always recall what they used to tell me and, sometimes, here at home, when I see him tired, not latching on right, I remember everything (M1).

[...] on the day I went to breastfeed her [daughter], the girl from the human milk bank came. [...] then she [nursing technician from the milk bank] said: 'keep thinking that she will latch on, that it's going to work'. I was already crying, because I thought she wouldn't latch on, then in the moment I put her to the nipple, she latched on and suckled, suckled, suckled until she was tired. From that moment, I decided that I would feed my daughter exclusively with breastmilk (M6).

At discharge from the hospital, they experience the following duality: they are instructed to make an effort and keep breastfeeding and, at the same time, they receive a formula prescription with instructions on how to use it. Formula is recommended only in necessary cases, when the PTNs have problems breastfeeding and must not lose weight. For twins, breastfeeding is even more complex.

Funny how they talk, talk about breastfeeding and then, at discharge, they give you a formula prescription. I took it, of course. I even bought it. What about the fear of him losing weight? (M9).

I give them milk from the breast and from the bottle, because I have to give them formula every three hours, as directed by the doctor. So, in that period, I can breastfeed them at will. Sometimes, when one of them is awake and already had her bottle, I give her the breast. When I notice they are angry, I give them the bottle [...] At discharge, everybody gets the prescription for the formula, everybody. It is safer, because you know how preterm babies are (M5).

The relationship with the workers remain latent in the mothers' memories and are activated when making decisions on the infants feeding during the whole period, especially when facing difficulties with $\mathrm{BF}$ at home.

\section{Unique traits of breastfeeding preterm infants}

During the infants' hospital stay, there is the tendency to understand BM as insufficient for preterm infants, because mothers see how scarcely BF is offered as first food to infants at the NICU and how predominant is the use of formula in this environment, especially when there are complications in weight gain. This leads to the understanding that formula is the solution for the PTNs' nutrition.

At the ICU, they administered formula with syringes, and they tried to help me breastfeed there, but she suckled too hard and got too tired and lost weight [...] then they instructed me to stop breastfeeding and we never tried the breast again, they simply gave her the formula, they didn't give my milk. [...] then she started gaining weight, and today she is home (M3).

Moreover, they see HM from the milk bank being offered to newborns with lower gestational ages and formula being offered to those with higher gestational ages or stable. Thus, they understand the use of formula or HM in stable infants as indifferent.

[...] at the ICU, they stopped giving him maternal milk early on. They gave it to the younger children because they needed it more. For my son, they gave the formula that is more similar to maternal milk [...]. The formula helped him, and so did my milk. Both are good, aren't they? (M4)

In spite of this context, there are mothers who value HM in preterm infant nourishment and who find differences when using formula. They recognize the practice of $\mathrm{BF}$ as beneficial for children in the spheres of nutrition and behavior. Therefore, they make an effort to perform it.

[...] and they [preterm infants] behave so nicely when they have breast milk [...] for preterm babies, it is better. It is better, it makes them calmer and we can be close together (M7).

Recognizing the value of HM leads the women to try to produce it and to see themselves as responsible for its production and with the obligation to make an effort to reach the neces- 
sary volume. Thus, they try to follow professional instructions for promoting milk production, ready to tolerate inconveniences, especially those related to the need to drink liquids and to milking.

Then I did the milking, I took good care of my breast, I washed, I hydrated, I ate well, I drank a lot of water, juice. She [nursing technician] said that the more liquid I drank, the better. So, I try to drink a lot of water, just as I learned to do in the nursery. I had to drink two glasses of water every hour. I said: 'you want me to make milk or to pee?' [laughs] (M1).

[...] milking is not easy, it hurts, it takes a long time, but when you see that you did it, that a lot of milk is coming out, wow, it's great, you keep doing it (M6).

When the infants are clinically stable, the workers encourage the mothers to breastfeed when they emphasize special measures because preterm infants have difficulties suckling and easily tire and choke. This causes tension during the $\mathrm{BF}$ process.

At the ICU, Dr. X let me breastfeed, because they were already healthy enough for it, then the nurses said: 'See, doctor? He won't latch on because he is too tiny and may choke'. You hear that and then you go breastfeeding. So tense (M8).

Down at the ICU, I breastfed. Of course he choked a little. He stopped breathing, he forgot to breathe. That was the biggest fear. He started suckling and then he choked, but the workers said it was normal, because he was preterm. I kept my eye on him all the time, especially if he was breathing. So frightening (M2).

When at home, the mothers reported trying to offer the breast, but they thought they produce an amount of milk that was insufficient to satisfy the infant and felt the need to offer formula as a complement.

My son is having the breast and the bottle. I have little milk, so my son is not satisfied, so I intercalate with bottles (M9).

As the days at home go on, baby formula prevails as the feeding resource for infants. All mothers in this study breastfed few times during the day, and preferred offering HM because they knew of its importance, but they believed their infants would be more satisfied with the formula. They adopted as guiding parameters for BF at home the infants' weight gain, breathing comfort during suckling and the volume of HM.

I fear my son losing weight and going back to the hospital, because of that, I end up giving him the breast and the bottle, I don't let him cry because of hunger, I feed him every two hours so he never loses weight (M4).

\section{Responsibilities for feeding infants}

When the infant arrives home, the mothers feel the socially imposed pressure (from workers, the social environment, and themselves) to nurture the infants well. In this sense, they ponder, through comparisons, the workers' actions and instructions and what they learned in their communities. Insecurities emerge concerning what is best for nourishing their infants, thus continuously encouraging their reflection. However, they tend to follow the recommendations from the workers, since they understand that the workers have more knowledge about preterm infants.

Oh, I fear doing something wrong and harming my daughters, you understand? Like, when they ask me, like, 'mother, you know you shouldn't have done this and you did this', you know? Like in the week I took them to the nutritionist, she said I could give them yogurt only after they were two, but I have a neighbor that gained weight eating it, then I started thinking about why children would eat yogurt after reaching two years of age. Some of the things they want, you won't follow if you see that it won't harm the child so much. However, I do follow some things, because I keep thinking that if I do it and something happens, and they have to be hospitalized, how could I look the doctor in the eye and tell her what happened? The doctor said they are preterm, we have to take it slow with them, so I try not to go overboard not to harm them and not to be questioned. So I prefer to follow what she is saying, they are doctors, they have experience, they don't want to hurt her, and neither do I (M5).

Instructions about the infants' feeding during the hospital stay and discharge make the mothers feel safe in the early stages at home. They act as a safe port, but tend to be adapted as time goes on, because the mothers feel gaps in the reasons that support them, with more questions concerning their pertinence to their infants. Despite that, they keep observing the instructions for fear of harming the infants.

In the ICU, he had to be fed every three hours and he had to take the complement, then we brought that discipline home, both me and my husband set alarms every three hours. That lasted until the fourth month (M4).

I started out doing everything like in the ICU, everything, everything. It made me calmer to repeat what I did there. But I understood that it wasn't like that, it seemed like something didn't fit, you know? [...] Today I try to feed my daughter according to what I think, according to what she likes (M6).

In this context of responsibility and insecurities, the infants' specificities demand flexibility in 
care and a break from the workers' instructions. Evidences for that are the infants' cries before the three-hour period between meals, the length of eructation, and the existence of twins with differing behaviors. With that, as the time at home goes on, they understand that it is impossible to bring home the rigidity of the NICU care routine and they increase the reflections with the aim to break away from them.

[...] breastfeeding at night was nerve-racking, because I couldn't go to bed and I was tired and I had to feed him at that time, because back at the nursery he had his meals every three hours at night, three in the morning, six in the morning, and that made the other one crazy, you know, because I had to wake up at that time and I thought I wouldn't be up to it because I felt so tired, really tired. I had to sit down, sometimes I stood up not to fall asleep, because I was afraid I would sleep and drown them with my milk (M8).

Attention to the comfort of the infants during and after feeding, both for the breast and for the bottle, is strongly present and linked to the idea that preterm infants are fragile, at-risk and that mothers are responsible for them. This limits changes in feeding practices, such as insisting on offering HM.

I don't have much milk, and as I offered the breast and he didn't want it, I couldn't leave him hungry, so I give him the bottle, and it breaks my heart, because, like, he has a tired lung and you let him cry. When it's a normal baby, you let it cry, but he isn't, it breaks your heart to let him cry, because I don't want to give him the bottle, I want to exclusively give the breast and, unfortunately, I have to give both, or else he cries a lot with only my milk (M9).

This is reinforced in the follow-ups, when they are questioned about how they are feeding the infants in coordination with the children's weight gain. In cases of weight loss, the workers emphasize the importance of feeding and the formula as a key resource.

[...] the doctor always told me my son should not lose weight, 'because if he does, he may have a worse disease and come back here'. That is my fear, going back to the hospital, that's why I feed him every three hours and I take good care of him. [name of the formula] has really helped his weight gain, as the doctor said (M8).

\section{DISCUSSION}

The workers' help and support for mothers can contribute to breastfeeding after hospital discharge. ${ }^{11}$ In this sense, information offered by workers of the NICU, the length of hospital stay ${ }^{12}$ and the professional care received by the mother encourage the acquisition of knowledge regarding the procedures, strategies and techniques for BF. As the mothers learn more about strategies, techniques and procedures related to $\mathrm{BF}$, they become more confident and empowered to adopt it as the only nutrition resource for their infants. ${ }^{5-6,11-12}$ However, when mothers do not receive information about milking and how to maintain HM production, they feel a lack of support for BF. ${ }^{11}$ It is noteworthy that the women in this study did not have the opportunity to explore the information they received, with results on the maintenance of $\mathrm{BF}$ at home. Entering the social, psychological universe and the reality of each woman must be part of the promotion, protection and support for $\mathrm{BF} .{ }^{13}$

Moreover, the collaboration between workers and mothers is more noticeable in the hospital environment, in comparison to the home environment, ${ }^{12,14}$ in a way that women feel helpless when facing problems with handling BF at home. This fact results in the interruption of HM offering and the introduction of the formula, ${ }^{5,11-12,15-16}$ which happened with the women in this research and was intensified by the duality in professional attitudes when handling the infants' nourishment.

The mothers shared the professional choice for the formula as a substitute for HM in the NICU and, sometimes, in the follow-up service, they confirm its success in helping infants gain weight. Therefore, in this study, as well as in others, ${ }^{11-12,15-16}$ formula was a solution for the infants' nourishment at home, and knowing how to offer it is one of the mothers' needs. ${ }^{11}$

We emphasize that the perception of the formula as a solution for preterm infant nutrition is a result of the women/mothers' position concerning the benefits of $\mathrm{BF}$ and what they learned at the NICU and at home in relation to the PTNs' nourishment. When considering the infants' safeness, the women in this study saw mixed feeding, with a predominance of formula, as the safest way, and received from health workers the interactions that convinced them of this. Differently from other mothers, the ones in this study did not contemplate changes in how they handled $\mathrm{BF}$ at home in order to expand it. ${ }^{17}$

The participation of workers in the promotion of $\mathrm{BF}$, beyond educationa $\mathrm{l}^{12}$ and encouragement ${ }^{15}$ processes, is pressing, with special attention to the congruence between discourse and practice. They influence BF and its maintenance 
at home $\mathrm{e}^{12,15}$ and can support the mothers of preterm infants, especially in overcoming their fears and insecurities. ${ }^{14}$ Still, they are part of the social interactions that result in the concept of preterm infant frailty ${ }^{11,15}$ and, as a consequence, promote super-protective actions toward PTNs, ${ }^{15}$ which, when at home, cause insecurities in handling BF and doubts about it. ${ }^{16}$

Results show a dilemma for the mothers to see themselves as "good mothers", since they did not choose BF exclusively. They mull over this issue, finding reasons for using formula as the primary type of nourishment for their infants in the idea that preterm infants are vulnerable and unstable, which is reinforced by health workers. This makes it clear that mothers decide how they will feed their preterm infants based on the idea that $\mathrm{HM}$ is essential, ${ }^{14}$ while breastfeeding is risky because of the PTNs unique characteristics.

As in other studies, exclusive BF was one the mothers' difficulties in caring for PTNs at home, ${ }^{15,18}$ with abandonment of the practice, ${ }^{18}$ use of infant formula and early introduction of foods as feeding practice of PTNs. ${ }^{11}$

Women in this study gave little attention to the practice of $\mathrm{BF}$ and closeness to their infants. We can infer that they were not made sufficiently aware of this question, because the interactive context that received them focused on the clinical complexity of the infants, the importance of weight gain and formula as a nutritional resource; aspects that permeated the experience of feeding PTNs at home. There is the possibility of maternal frustration for not being able to exclusively breastfeed the infants. ${ }^{11}$ With this, the mothers were barred from recognizing other nuances that are part of the act of breastfeeding, among which is the conveyance of affection and pleasure in the act by itself.

The collected data show that mothers reached for the best for their infants, which is evidence of the ties between them. However, they could not achieve exclusive BF as a resource for that end, which is the opposite of what happened to other mothers in international contexts that put higher value on the mother/infant relationship. ${ }^{14,17,19}$ Mixed feeding was the predominant practice after hospital discharge in this study, as well as in another one. ${ }^{11}$

Breastfeeding is a social practice, therefore, it depends on beliefs, values and socializing processes that are community-specific. ${ }^{13}$ The exploration of the perception of collectives (family and community) concerning preterm infant BF would contribute for enhancing the understanding of the phenomenon. Thus, when mothers find themselves insecure in relation to the infants' $\mathrm{BF}$, they look for their families and follow their instructions. ${ }^{11,13}$ It is known that family support and encouragement is of great importance for BF. ${ }^{13}$

The authors of this study heard mothers that received care at an NICU that does not adopt the humanizing concepts disseminated by the Ministry of Health, with limits for visitation and contact between mothers and infants. Hearing mothers that experienced NICU environments with "Child Friendly" credentials may show counterpoints in these interactive environments and their influence on $\mathrm{BF}$ practice for preterm infants at home. We suggest exploring the perception of workers from the NICUs and follow-up services concerning the intention of acts for the promotion, support and encouragement for breastfeeding PTNs.

The period after hospital discharge of preterm infants can be explored in studies that aim to contribute for the care offered to infants and families in follow-up services and in childcare actions in primary health care services.

\section{CONCLUSION}

The time spent at the NICU strongly influences the handling of BF at home, especially interactions with health workers, since they promote the understanding that breastfeeding can harm preterm infants. They point to the formula as an effective resource for nourishing these infants, based on weight gain.

There is informational support, however, without context and in disagreement with professional practice, which causes a dualism and results in insecurities for mothers to perform BF at home.

\section{REFERENCES}

1. World Health Organization. The optimal duration of exclusive breastfeeding. Geneva: WHO; 2001.

2. United Nations Children's Fund. Promovendo o aleitamento materno, 2008. [acesso 2013 Dez 28]. Disponível em: http:/ / www.unicef.org.brazil/pt/ aleitamento.pdf

3. Ministério da Saúde (BR). Saúde da criança. Nutrição infantil: aleitamento materno e alimentação complementar. Brasília (DF): Ministério da Saúde; 2009.

4. Czechowski AE, Fujinaga CI. Seguimento ambulatorial de um grupo de prematuros e a prevalência do aleitamento na alta hospitalar e ao 
sexto mês de vida: contribuições da fonoaudiologia. Rev Soc Bras Fonoaudiol. 2010 Dez; 15(4):572-7.

5. Paiva CVA, Saburido KAL, Vasconcelos MN, Silva MAM. Aleitamento materno de recém-nascidos internados: dificuldades de mães com filhos em unidade de cuidados intensivos e intermediários neonatais. Rev Min Enferm. 2013 Out-Dez; 17(4):932-9.

6. Boucher CA, Brazal PM, Graham-Certosini C, Carnaghansherrard K, Feeley N. Mothers' breastfeeding expiriences en the NICU. Neonatal Netw. 2011 Jan-Fev; 30(1):21-8.

7. Charon JM. Symbolic interacionism: an introduction, an interpretacion, an integration. Englewood Cliffs: Prentice Hall; 1989.

8. Vaismoradi M, Turunen $\mathrm{H}$, Bondas T. Content analysis and thematic analysis: implications for conducting a qualitative descriptive study. Nurs Health Sci. 2013 Sept; 15(3):398-405.

9. Elo S, Kynga SH. The qualitative content analysis process. J Adv Nurs. 2008 Apr; 62(1):107-15.

10. Deslauriers JP, Keriset M. O delineamento de pesquisa qualitativa. In: Poupart J, organizador. A pesquisa qualitativa: enfoques epistemológicos e metodológicos. Rio de janeiro (RJ): Vozes; 2008. p.127-53.

11. Melo LM, Machado MMT, Leite AJM, Rolim KMC. Prematuro: experiência materna durante amamentação em unidade de terapia intensiva neonatal e pós-alta. Rev Rene. 2013 Jul-Ago; 14(3):512-20.

12. Cabral IE, Groleau D. Breastfeeding practices after kangaroo mother method In Rio de Janeiro: the necessity for health education and nursing intervention at home. Esc Anna Nery. 2009 Oct-Dec; 13(4):763-71.

13. Moreira MA, Nascimento ER, Paiva MS. Representações sociais de mulheres de três gerações sobre práticas de amamentação. Texto Contexto Enferm [online]. 2013 Abr-Jun; 22(2):432-41. [acesso 2013 Dez 08]. Disponível em: http://www.scielo. $\mathrm{br} /$ scielo.php? script $=$ sci_arttext\&pid=S010407072013000200020\&lng=pt\&nrm=iso\&tlng $=p t$

14. Silva RV, Silva IA. A vivência de mães de recémnascidos prematuros no processo de lactação e amamentação. Esc Anna Nery Rev Enferm. 2009 Jan-Mar; 13(1):108-15.

15. Souza NL, Fernandes ACP, Costa ICC, Enders BC, Carvalho JBL, Silva MLC. Domestic maternal experience with preterm newborn children. Rev Salud Publica. 2010; 12(3):356-67.

16. Pacheco STA, Cabral IE. Alimentação do bebê de baixo peso no domicílio: enfrentamentos da família e desafios para a enfermagem. Esc Anna Nery. 2011 Abr-Jun; 15(2):314-22.

17. Morais AC, Quirino MD, Almeida MS. O cuidado da criança prematura no domicílio. Acta Paul Enferm. 2009 Jan-Fev; 22(1):24-30.

18. Caetano LC, Nascimento GS, Nascimento MCA. A família e a prática de amamentação em bebês de baixo peso ao nascer. Rev Eletr Enferm [online]. 2011 Jul-Set; 13(3):431-8. [acesso 2013 Dez 28]. Disponível em: http://www.revistas.ufg.br/index.php/fen/ article/view/10646/10644

19. Lee TY, Lee TT, Kuo SC. The experiences of mothers in breastfeeding their very low birth weight infants. J AdvNurs. 2009 Dec; 65(12):2523-31. 